\title{
SI gene sequence analysis of new variant isolates of avian infectious bronchitis virus in Tunisia
}

This article was published in the following Dove Press journal:

Veterinary Medicine: Research and Reports

12 July 2012

Number of times this article has been viewed

\section{Hager Bourogâa \\ Imen Hellal \\ Jihene Hassen \\ Imen Fathallah \\ Abdeljelil Ghram}

Laboratoire d'Epidémiologie et de Microbiologie Vétérinaire, Institut Pasteur de Tunis, Tunis, Tunisia
Correspondence: Hager Bourogâa Laboratory of Epidemiology and Veterinary Microbiology, Institut Pasteur de Tunis, I3 Place Pasteur, BP 741002

Tunis, Tunisia

Tel $+2167|845| 44$

$\mathrm{Fax}+21671791833$

Email hager.bourogaa@gmail.com
Purpose: Tissue samples were collected from suspected broiler flocks showing respiratory signs to identify infectious bronchitis virus (IBV), characterize emerging field strains, and study their relationships with the Massachusetts H120 strain, the only IB vaccine used in Tunisia.

Samples and methods: Several IBV isolates were identified from field samples collected from flocks located in different regions in the northeast of Tunisia. The IBV isolates were characterized and compared to commonly used vaccine strains (including 793B, D274, and H120 types), other reference IBV strains from Europe, and the recently characterized Tunisian field variants TN20/00, TN200/01, and TN335/01. Reverse transcription-polymerase chain reaction and nucleotide sequencing analyses of the hypervariable regions of the $\mathrm{S} 1$ gene were carried out.

Results: Four new IBV variants were isolated during the period 2007-10 and were designated TN295/07, TN296/07, TN556/07, and TN557/07. The amino acid sequence data showed 100\% similarity between TN295/07 and TN296/07, suggesting that these two isolates are identical and belong to the same genotype. Similar results were demonstrated for TN556/07 and TN557/07. Sequence identity values indicated that TN296/07 and TN556/07 share 55\% amino acid homologies between each other, but are very different from the reference IBV serotypes, in particular the $\mathrm{H} 120$ strain. It was also shown that they have $50 \%-77 \%$ similarities with the Tunisian virus isolated between 2000 and 2001. Phylogenetic clustering allowed classification of these Tunisian isolates as new genotypes that are closer to TN200/01, TN335/01 Tunisian field variants, and Italy02 variant than MassH120 vaccine strain.

Conclusion: S1 sequence analyses confirmed the cocirculation of H120 vaccine strain with novel IBV variants isolated from Tunisian field.

Keywords: IBV, new genotypes, RT-PCR, S1 gene sequencing, phylogeny analysis, Tunisia

\section{Introduction}

Infectious bronchitis virus (IBV) belongs to group 3 of the genus Coronavirus of the family Coronaviridae. It possesses a positive-stranded RNA genome encoding nucleocapsid protein $(\mathrm{N})$, membrane glycoprotein $(\mathrm{M})$, spike glycoprotein $(\mathrm{S})$, and small membrane protein. The S protein is posttranslationally cleaved into S1 and S2. The $\mathrm{S} 1$ protein contains antigenic epitopes associated with three hypervariable regions (HVR 1, 2, and 3), and variations within S1 sequences have been used to distinguish between different IBV serotypes. ${ }^{1}$

Avian infectious bronchitis, a worldwide-distributed disease, is associated with an acute and a highly contagious infection of poultry. ${ }^{2}$ It causes respiratory distress, drops in egg production, and nephritis. ${ }^{3}$ The disease has also been reported in vaccinated 
flocks since cross-protection among different serotypes may be unpredictable, ${ }^{4}$ even though high-quality live and killed vaccines have been used as the primary method for controlling IBV infection in commercial chickens for many years. ${ }^{5}$ However, high cross-protection levels were successfully reported in monitoring the disease effects using currently available vaccines. ${ }^{6}$

Despite the development of vaccines that contribute to the control of the clinical disease, the emerging field virus variants remain a target that is difficult to monitor. Many serotypes have been described for IBV due to the nature of coronaviruses that show frequent mutations or recombinations, which easily occur in RNA viruses, leading to novel pathogenic variants. ${ }^{7,8}$ In most cases, the new isolates have restricted distribution and remain associated with particular geographic areas. ${ }^{2,9}$

In Tunisia, field variant strains were described and associated with outbreaks of respiratory disease and nephritis with rapid spread. The novel genotypes TN20/00, TN200/01, and TN335/01 were shown to be serologically and genetically very distant from the Mass H120 vaccinal strain, but closely related to the CR88121 and D274 types. ${ }^{10}$ Despite the application of a prophylactic program, based on the H120 vaccine, the results were unsatisfactory. ${ }^{11}$ Therefore, efforts are continually being made to identify and characterize field isolates, allowing better understanding of IBV pathogenicity for better disease control.

As part of a molecular epidemiological survey based on the study of IBV S1 gene sequences, the present work was carried out to characterize new field isolates using molecular tools and establish genetic and antigenic relationships between field virus variants and available vaccine strains.

\section{Materials and methods Clinical samples}

Chickens with respiratory and kidney problems, from several broiler and layer commercial flocks, were sampled. These outbreaks of IB infection occurred between 2007 and 2010 in different farms in the northeast of Tunisia. Reports from veterinarians described clinical signs, consistent with IB infections, seen in broilers aged 3-7 weeks with a morbidity rate ranging from $10 \%$ to $70 \%$. In layers, mortality, egg drop, and deformed eggs were the most relevant symptoms reported. Thirty-six organ samples from these farms were collected during that period and tested for the presence of IB virus. The flocks were located in seven different regions from the northeast of the country: the capital, Tunis, Soliman,
Mornag, Jedaida, Haouaria, Tazarka, and Korba. The flocks were vaccinated by spray with H120 vaccine, the only vaccine used in the country, in conjunction with sustained hygienic measures.

Tissue samples from trachea, lungs, kidneys, and cecal tonsils were kept on ice, in sterile transport medium containing $5 \%$ antibiotics $(20,000 \mathrm{IU} / \mathrm{mL}$ penicillin, $10,000 \mu \mathrm{g} / \mathrm{mL}$ streptomycin, and $5000 \mu \mathrm{g} / \mathrm{mL}$ kanamycin) and treated directly for virus isolation.

\section{Virus isolation in chicken embryos}

Specimens were homogenized with Dulbecco's modified Eagle's medium, clarified by centrifugation at $1500 \times \mathrm{g}$ at $4^{\circ} \mathrm{C}$ for 15 minutes and filtered through nonpyrogenic syringe filter $(0.22 \mu \mathrm{m})$ before inoculation into allantoic cavities of 10-day-old specific-pathogen-free embryonated chicken eggs. During the incubation period at $37^{\circ} \pm 5^{\circ} \mathrm{C}$, the eggs were candled daily, and embryos that died within 24 hours were discarded. On day 2 after inoculation, three eggs were chilled at $4^{\circ} \mathrm{C}$ for 2 hours, and the allantoic fluids were harvested and stored at $-80^{\circ} \mathrm{C}$. The remaining eggs were further incubated for five more days and observed for typical embryo lesions of IBV such as dwarfing, stunting, and curling. The stored allantoic fluids were further passaged twice into specific-pathogen-free eggs before samples, free of any specific lesions, were declared negatives.

\section{RNA extraction}

Viral RNA was extracted from $500 \mu \mathrm{L}$ allantoic fluid. A volume of $500 \mu \mathrm{L}$ proteinase $\mathrm{K}$ buffer (1 M Tris, $5 \mathrm{M} \mathrm{NaCl}, 0.5 \mathrm{M}$ ethylenediaminetetraacetic acid), and $20 \mu \mathrm{L}$ proteinase K (Sigma-Aldrich, Lyon, France; final concentration $0.25 \mathrm{mg} / \mathrm{mL}$ ) were added to the allantoic fluids. A volume of $50 \mu \mathrm{L}$ sodium dodecyl sulphate $10 \%$ (w/v) was added to the mixture, which was incubated at $37^{\circ} \mathrm{C}$ for 2 hours. Viral RNA was then extracted by two consecutive acid phenol-chloroform-isoamyl alcohol (500 $\mu \mathrm{L}, 25: 24: 1)$ (Sigma-Aldrich) isolations. The mixtures were agitated, kept on ice for 5 minutes, and centrifuged at $12,000 \times \mathrm{g}$. The aqueous phase containing RNA was mixed with $1 \mathrm{~mL}$ of absolute alcohol and $2 \mathrm{M}$ sodium acetate, and kept at $-80^{\circ} \mathrm{C}$ for 30 minutes. The supernatant was removed, and the precipitated RNA was pelleted at $12,000 \times \mathrm{g}$ for 20 minutes and washed once with $0.5 \mathrm{~mL}$ of $70 \%$ ethanol. Finally, the pellet was dried and suspended in $20 \mu \mathrm{L}$ diethyl pyrocarbonate-treated water and used immediately or stored at $-80^{\circ} \mathrm{C}$ with $1 \mu \mathrm{L}$ RNAsin. 


\section{RT-PCR for nucleocapsid gene (N) detection}

Viral RNA was amplified by reverse transcription-polymerase chain reaction (RT-PCR) assay using one set of primers flanking a well-conserved region of the nucleocapsid gene: forward 5'-TCATGGCAAGCGGTAAGG-3' and reverse 5-'TTCAGGTTAGCGGCTGGTC-3' (Genset, Paris, France).${ }^{12,13}$ For cDNA synthesis, a mixture of $20 \mu \mathrm{M}$ of the reverse primer and $20 \mu \mathrm{L}$ of the RNA was incubated at $70^{\circ} \mathrm{C}$ for 10 minutes and then cooled on ice. The RNA-primer mixture was adjusted to a final volume of $30 \mu \mathrm{L}$, containing 5X RT buffer, $0.1 \mathrm{M}$ dithiothreitol, $10 \mathrm{mM}$ dNTPs and 40 U Moloney murine leukemia virus (Invitrogen, Carlsbad, CA), followed by incubation at $42^{\circ} \mathrm{C}$ for 1 hour. The reverse transcriptase was then inactivated by heating the mixture at $70^{\circ} \mathrm{C}$, and $20 \mu \mathrm{M}$ of each primer, $10 \mathrm{X}$ buffer, $50 \mathrm{mM} \mathrm{MgCl}_{2}$, $10 \mathrm{mM}$ dNTPs and $1 \mu \mathrm{L} \mathrm{Taq}$ polymerase (Invitrogen) were added for cDNA amplification. Each sample was overlaid with water RNase free to a total volume of $100 \mu \mathrm{L}$. The PCR was conducted and performed with 30 cycles of denaturation at $94^{\circ} \mathrm{C}$ for 1 minute, annealing at $55^{\circ} \mathrm{C}$ for 1 minute, and polymerisation at $72^{\circ} \mathrm{C}$ for 1 minute. The initial denaturation and the final polymerisation steps were at $94^{\circ} \mathrm{C}$ for 5 minutes and $70^{\circ} \mathrm{C}$ for 10 minutes, respectively. The PCR products $(316 \mathrm{pb})$ were analysed on a $2 \%$ agarose gel.

\section{RT-PCR for SI gene detection}

Amplification of the S1 gene by RT-PCR was performed using the primers set forward 5'-CCCAATTTGAAAACTGAACA-3' and reverse $5^{\prime}$ CCTACTAATTTACCACCAGA- $3^{\prime} .{ }^{14}$ To obtain the cDNA, the reverse primer $(20 \mu \mathrm{M})$ was added to $20 \mu \mathrm{L}$ template RNA and incubated for 10 minutes at $70^{\circ} \mathrm{C}$. After a quick standing on ice for 5 minutes, $5 \mathrm{X}$ RT buffer, $0.1 \mathrm{M}$ dithiothreitol, $10 \mathrm{mM}$ dNTPs, and $1 \mu \mathrm{L}$ of SuperScript II (Invitrogen) were added and the mixture was incubated at $42^{\circ} \mathrm{C}$ for 90 minutes. The reaction was stopped at $70^{\circ} \mathrm{C}$ for 15 minutes. For cDNA amplification, 10X PCR buffer, $50 \mathrm{mM} \mathrm{MgCl}, 10 \mathrm{mM}$ dNTPs, and $10 \mu \mathrm{M}$ of each primer were gently mixed to a final volume of $100 \mu \mathrm{L}$. After the predenaturation step at $94^{\circ} \mathrm{C}$ for 5 minutes, $0.5 \mu \mathrm{L}$ Taq DNA polymerase was added. The whole PCR program was performed with 35 cycles of denaturation at $94^{\circ} \mathrm{C}$ for 1 minute, annealing at $49^{\circ} \mathrm{C}$ for 1 minute and polymerisation at $72^{\circ} \mathrm{C}$ for 3 minutes. The postpolymerisation step was at $72^{\circ} \mathrm{C}$ for 7 minutes. After gel electrophoresis, the predicted S1 band of $1.6 \mathrm{~kb}$ was cut from the gel and purified using the Gene Clean Kit (Bio101, Vista, CA), according to the manufacturer's recommendations.

\section{Nested PCR and DNA sequencing}

After the first run of S1 gene amplification, $1 \mu \mathrm{L}$ of the PCR product was further amplified using the internal primers: CK4T7 (5'-TAATACGACTCACTATAGGGATGCTACTAGTCAAAGCTTCANGGNGGNGCNTA-3') and CK2 (5'-CTCGAATTCCNGTRTTRTAYTGRCA-3'). ${ }^{15}$ The thermal profile of the second run of amplification was $94^{\circ} \mathrm{C}$ for 15 seconds, $50^{\circ} \mathrm{C}$ for 45 seconds, and $72^{\circ} \mathrm{C}$ for 1 minute, with a final elongation step of 10 minutes at $70^{\circ} \mathrm{C}$. Nested PCR amplification was performed for 45 cycles. For visualisation, $10 \mu \mathrm{L}$ of PCR products was electrophoresed on a $2 \%$ agarose gel. The nested PCR products $(610 \mathrm{pb})$ containing HVR1, HVR2, and HVR3 were purified and sequenced. Determination of the nucleotide sequences was performed using the Prism Ready Reaction Dye Deoxy Terminator Cycle Sequencing Kit on an ABI Prism 377 DNA sequencer (Applied Biosystems, Foster City, CA).

\section{Nucleotide and amino acid deduced sequence analyses}

Assembly and analysis of sequence data were conducted using the BioEdit program. Nucleotide and amino acid deduced sequences were aligned using ClustalW. Phylogenetic analyses and tree construction, performed by the neighbor-joining method with 1000 bootstrap replicates, were conducted with MEGA software. Glycosylation sites were determined using the Prosite program. ${ }^{16}$

GenBank accession numbers of the reference strains H120 (M21969); QX (AER08736); D274 (X15832); 4/91 (AF093794); CR88121 (AJ 619609); B1648 (X87238); Italy02 (AJ457137); TN335/01 (EF535996); TN200/01 (EF5359 97); TN20/00 (535998).

\section{Results and discussion}

Currently, genotyping is by far the most used tool in this field, having largely replaced serotyping IBV strains, and the use of molecular techniques for isolation and genotyping IBVs has resulted in increased interest in the detection of new IBV variants. The present study shows the current situation of IBV in the northeast of Tunisia associated with the identification of IBV isolates as novel variants that are unrelated to reference strains using RT-PCR and sequencing methodologies.

During the years 2007-10, five IBVs were isolated from trachea, lungs, kidneys, and cecal tonsils from 4-5-week-old broiler chickens (Table 1) with suspected clinical signs and reared in different regions around the capital, Tunis. Virus 
Table I Characterization of Tunisian infectious bronchitis virus isolates from broiler chickens

\begin{tabular}{|c|c|c|c|c|c|}
\hline $\begin{array}{l}\text { Isolate } \\
\text { designation }\end{array}$ & $\begin{array}{l}\text { Age of chickens } \\
\text { (days) }\end{array}$ & Clinical signs & $\begin{array}{l}\text { Geographic } \\
\text { origin }\end{array}$ & $\begin{array}{l}\text { Isolate } \\
\text { type }^{a}\end{array}$ & $\begin{array}{l}\text { GenBank } \\
\text { accession numbers }\end{array}$ \\
\hline TN295/07 & 31 & $\begin{array}{l}\text { Diarrhea } \\
\text { Tracheitis } \\
\text { Nephritis }\end{array}$ & Soliman, south of Tunis & Variant & 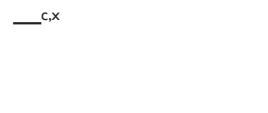 \\
\hline TN296/07 & 37 & Respiratory distress & Jedaida, north of Tunis & Variant & FJ716133 \\
\hline TN556/07 & 30 & Nephritis & Tunis & Variant & FJ716132 \\
\hline TN557/07 & 30 & $\begin{array}{l}\text { Nephritis } \\
2 \% \text { mortality/flock }\end{array}$ & Mornag, south of Tunis & Variant & $\square^{y}$ \\
\hline TNI084/08 & 31 & $\begin{array}{l}\text { Diarrhea } \\
\text { Nephritis } \\
\text { Tracheitis } \\
2 \% \text { mortality/flock }\end{array}$ & Mornag, south of Tunis & Mass & $一^{2}$ \\
\hline
\end{tabular}

Notes: aldentification by serological and reverse transcription-polymerase chain reaction analyses; ${ }^{\mathrm{b}}$ GenBank accession numbers for the hypervariable region of SI gene sequence of the novel infectious bronchitis virus genotypes; 'sequence not submitted to GenBank; x,y,zidentical to SI gene sequence of TN296/07, TN556/07 and HI20 strains, respectively.

identification was realized and ascertained by RT-PCR and $\mathrm{S} 1$ gene sequence analyses. Despite a dual vaccination with MassH120 strain, broilers from which isolates were recovered showed typical IB clinical symptoms and produced typical embryo lesions (stunting, dwarfing, and curling) after three serial passages in chicken embryos. RT-PCR using primers amplifying the $\mathrm{N}(316 \mathrm{pb})$ and the $\mathrm{S} 1(1600 \mathrm{pb})$ genes confirmed the identity of the five IBV isolates.

The isolates were further characterized by sequencing the HRV regions of $\mathrm{S} 1$ gene, which were compared then aligned, showing 100\% amino acid sequence similarity between TN295/07 and TN296/07, isolated from different broiler flocks located in two different regions (Soliman and Jedaida, respectively). The results indicated that they are identical to each other and belong to the same genotype. Similar results were also observed for TN556/07 and TN557/07 genotypes, even though they were isolated from different areas (Tunis and Mornag, respectively). High amino acid similarity was demonstrated between TN1084/08 and Mass H120 genotypes, and the phylogeny results indicated that TN1084/08 isolate belongs to the same genetic cluster as MassH120 virus, inferring that it should be considered as the H120 vaccine strain (Figures 1 and 2).

Considering nucleotide and amino acid identities of HVR S1 gene sequences (Table 2), 55\% amino acid homology was shown for TN296/07 and TN556/07 isolates, whereas 46\% and 55\% similarities were displayed when they were compared to CR88121 vaccinal strain, respectively. However, the amino acid content of HVR subunit of TN296/07 isolate showed only $18 \%$ and $17 \%$ similarities with MassH120 and D274 vaccinal strains, respectively; while TN556/07 isolate shared 20\% homology with these two reference genotypes. The results indicated that TN296/07 and TN556/07 differed from all the vaccine strains included in this study, suggesting that the Tunisian isolates were not reisolation of vaccinal virus. Furthermore, phylogenetic analysis showed that 793B serotype strains (4/91 and CR88121 vaccines) are closer to the Tunisian isolates than Massachusetts H120 and D274 vaccinal strains (Figure 1). The comparisons of S1 gene sequences of representative strains of different serotypes isolated from several countries in North America, Europe, and Africa (Mass strain: H120; Doorn strain: D274; 793B strains: 4/91, CR88121; QX strain; Italy 02 strain; Belgium B1648 strain and TN256/07, TN556/07 isolates) showed a high degree of variation (Figure 2) and differences in their S1 amino acid sequences ( $\geq 25 \%)$. When compared to Italy 02 strain, the two Tunisian TN256/07, TN556/07 isolates showed the closest nucleotide (64\%) and amino acid identities $(\leq 75 \%)$ (Table 2$)$. As reported by other studies, ${ }^{17-20} \mathrm{IBV}$ serotypes were usually shown to differ, in their $\mathrm{S} 1$ amino acid sequences, by only $20 \%-25 \%$ and as little as $3 \%$ in many cases; thus, TN296/07 and TN556/07 field isolates should be considered as different new serotypes. Phylogenetic analyses confirmed these findings and demonstrated that TN296/07 and TN556/07 isolates form a separate phylogenetic cluster more related to the local TN200/01 and TN335/01 strains (isolated in 2001) than other reference strains (Figure 1).

$\mathrm{S} 1$ sequence comparisons showed significant differences in nucleotide and amino acid sequences of HVR regions of TN296/07 isolate with either TN20/00 field variant isolate (44\% nucleotide and 52\% amino acid identities) or TN335/01 (50\% nucleotide and amino acid identities). The HVR of TN556/07 isolate also indicated considerable variability as compared to either TN20/00 (54\% nucleotide and 62\% amino acid identities) or TN335/01 (64\% nucleotide and $72 \%$ amino acid identities) (Table 2 ). The point mutations, 


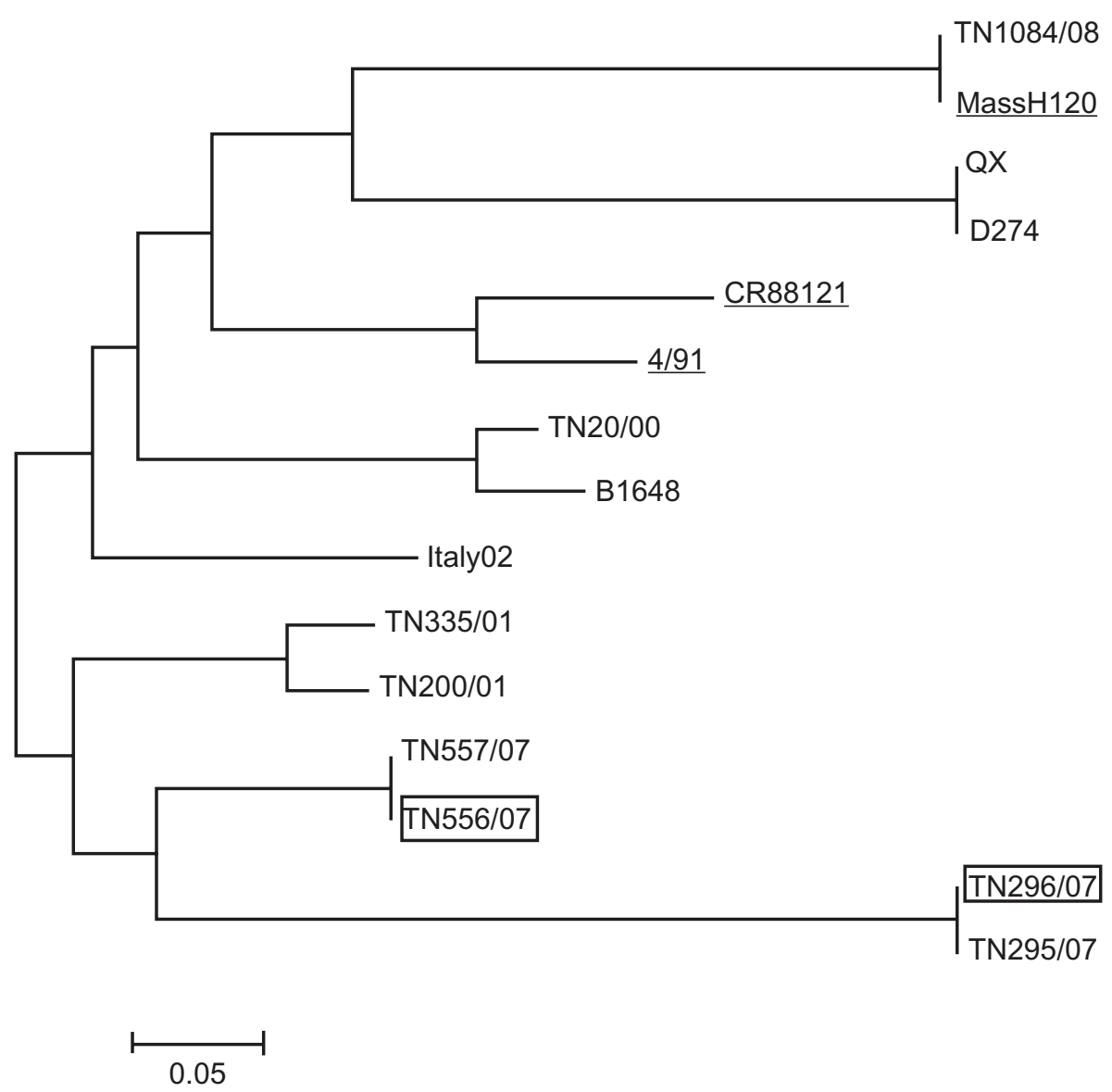

Figure I Neighbor-joining phylogenetic tree with 1000 bootstrap replicates expressing the relationships among deduced SI amino acid sequences of TN296/07 and TN556/07 with selected infectious bronchitis virus reference strains.

Notes: Horizontal branches indicate the sequence distance (number of amino acid substitutions per site) drawn to scale. The reference vaccine strains are underlined. The new Tunisian isolates are in boxes.

deletions or insertions observed within the HVR of S1 gene sequences were associated with changes potential in glycosylation motifs and antigenic S1D and S1E sites, at amino acid positions $\mathrm{aa}_{49-61}$ and $\mathrm{aa}_{131-149}$, respectively (Figure 2) that may lead to important changes in the antigenicity and the degree of virulence of IBV, as reported by others. ${ }^{21-25}$ Consequently, sequence analyses and phylogeny data confirmed the identification of two novel IBV field variant genotypes coexisting in Tunisian broiler flocks. In addition, it appears that these isolates are unique and have extensive variability in their S1 gene sequences compared to each other, to recently reported Tunisian field variants, and to other reference genotypes (Figure 2).

The emergence of the two new genotypes may be related to the two major forces that drive coronavirus evolution: mutation due to high error rates of the viral RNA polymerase and recombination. Thus, phylogeny results showed that TN296/07 and TN556/07 genotypes are very closely related to the Tunisian TN200/01 IBV variant. Besides, the sequenc- ing results demonstrated that TN200/01 shares the highest nucleotide and amino acid similarities with either TN296/07 (51\% nucleotide and 59\% amino acid identities) or TN556/07 (70\% nucleotide and 77\% amino acid identities) (Figures 1 and 2). Therefore, one can infer that genetic events accumulated during time in TN200/01, inducing the emergence of new genotypes that differ from the parental one.

However, when proper vaccination programs are implemented with one genotype (MassH120 type, in Tunisia), control of the disease may be achieved and provides a selective means for the emergence of new variant genotypes. ${ }^{26}$ This hypothesis thus leads us to address the question of whether positive selection pressures might have driven H120 strain evolution, resulting in the emergence of new IBV variants in the field. This idea can be supported by the fact that although Mass H120 virus shows low identities with field isolates, the HVR sequence analyses indicated that field isolates share and possess 12 identical amino acid substitutions as compared to H120 genotype, at amino acid positions 76, 78, 93, 103, 


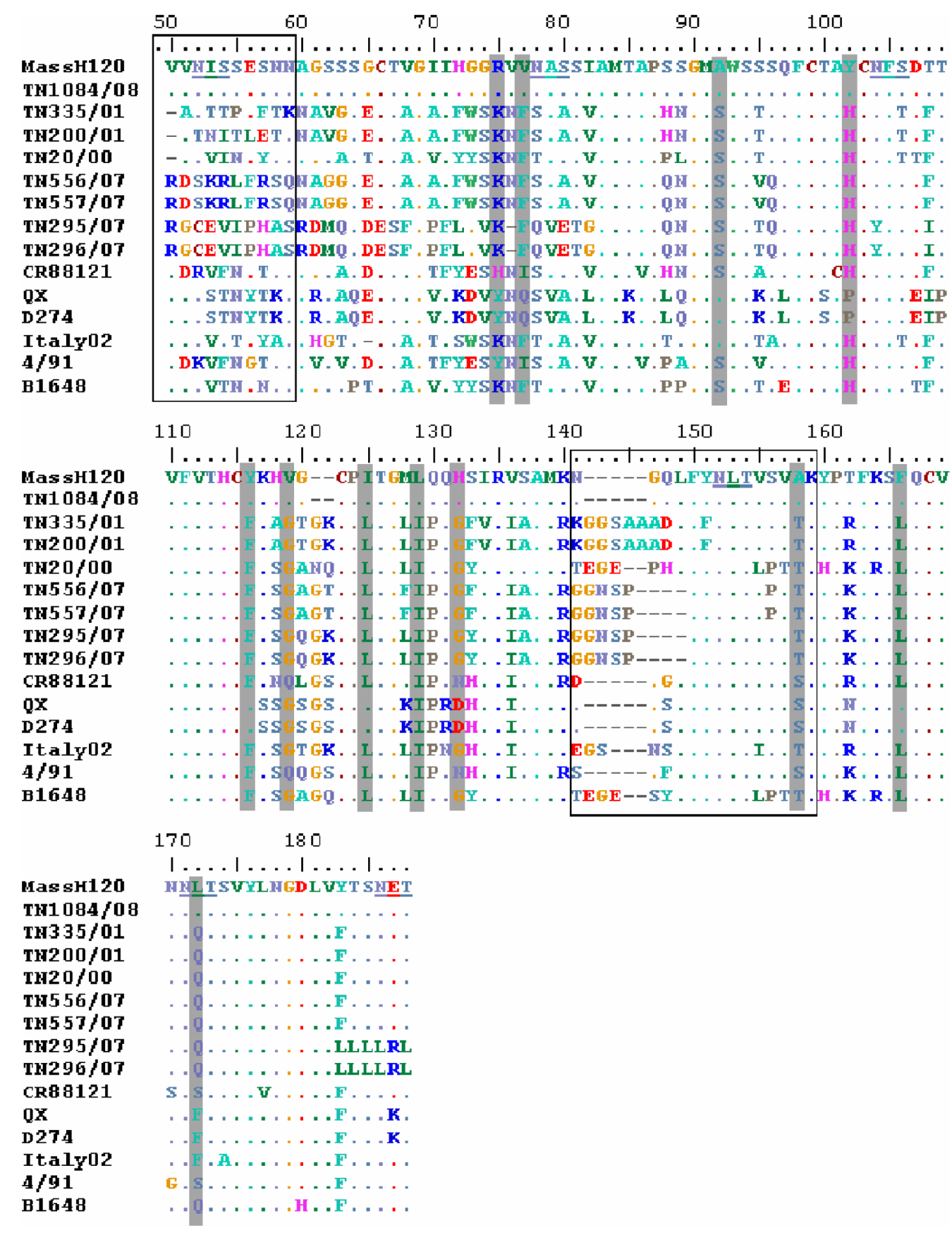

Figure 2 Alignment of deduced amino acid sequences of HVR SI gene. New Tunisian isolates, old Tunisian field isolates and selected infectious bronchitis virus reference strains. Notes: Dots indicate identical residues. Boxed letters denote antigenic sites SID $\left(\mathrm{aa}_{49-61}\right)$ and SIE (aa $\left.{ }_{131-149}\right)$. Shaded letters indicate identical substitutions compared to MassH 20. Potential N-glycosylation sites are underlined.

$117,120,126,130,133,159,167$, and 173 (Figure 2). We may suppose that these genetic events have occurred within a common parental strain (probably during H120 genome replication), then conserved during time among the new emerging field isolates. In addition, these amino acid substitutions are located in HVR2 for the amino acid residues 76-173, and it was well documented that HVR2 contains sequences associated with IBV serotype-specific neutralizing epitopes. Besides, the region between amino acid residues
123-152 was identified as being involved in differentiating the pathogenicity of some IBV strains. ${ }^{27}$ Therefore, because of high sequence differences between both TN296/07 and TN556/07 isolates and reference IBV strains, the newly identified genotypes may express new serotypes. Partial or total sequencing of the $\mathrm{S} 1$ gene is useful to genotype and identify new serotypes..$^{28}$ In fact, it has been demonstrated that in some cases small differences in amino acid sequence of the $\mathrm{S} 1$ protein can be sufficient to lead to serotype change 
Table 2 Nucleotide and amino acid identities of TN296/07 and TN556/07 isolates with selected infectious bronchitis virus sequences

\begin{tabular}{|c|c|c|c|c|c|c|c|c|c|c|c|c|}
\hline \multicolumn{13}{|c|}{ SI nucleotide identity ${ }^{\mathrm{a}}(\%)$} \\
\hline Strain & TN296/07 & TN556/07 & TN20/00 & TN200/0I & TN335/0I & $\mathrm{HI} 20$ & D274 & CR88/I2I & $4 / 91$ & It-02 & QX & BI648 \\
\hline TN296/07 & & 50 & 44 & 51 & 50 & 8 & 8 & 40 & $4 \mid$ & 42 & 35 & 39 \\
\hline TN556/07 & 55 & & 54 & 70 & 64 & 9 & 8 & 47 & 62 & 64 & 51 & 61 \\
\hline TN20/00 & 52 & 62 & & 58 & 53 & 50 & 57 & 49 & 57 & 60 & 49 & 76 \\
\hline TN200/0I & 59 & 77 & 69 & & 81 & 57 & 70 & 50 & 61 & 69 & 52 & 62 \\
\hline TN335/0I & 50 & 72 & 64 & 82 & & 50 & 63 & 49 & 55 & 62 & 49 & 56 \\
\hline $\mathrm{HI} 20$ & 18 & 20 & 64 & 71 & 63 & & 72 & 47 & 68 & 71 & 68 & 69 \\
\hline D274 & 17 & 20 & 78 & 78 & 70 & 87 & & 47 & 69 & 67 & 100 & 63 \\
\hline CR88I2I & 46 & 55 & 57 & 60 & 57 & 61 & 57 & & 64 & 50 & 47 & 48 \\
\hline $4 / 91$ & 45 & 70 & 65 & 69 & 64 & 82 & 79 & 69 & & 73 & 69 & 71 \\
\hline It-02 & 50 & 75 & 68 & 77 & 73 & 82 & 77 & 59 & 82 & & 67 & 76 \\
\hline QX & 44 & 65 & 60 & 65 & 61 & 79 & & 57 & 78 & 77 & & 63 \\
\hline BI648 & 45 & 72 & 79 & 74 & 69 & 81 & 76 & 57 & 81 & 85 & 76 & \\
\hline \multicolumn{13}{|c|}{ SI amino acid similaritya $(\%)$} \\
\hline
\end{tabular}

and indeed absence of cross-protection..$^{29}$ Therefore, studies investigating antigenic relatedness between new genotypes using seroneutralization techniques are necessary to finally classify them as new serotypes.

\section{Conclusion}

The present study revealed the coexistence of novel emerging field IBV genotypes, which had not been reported before. The identified strains were isolated from young broilers indicating the serious occurrence of IBV infection and its persistence, especially in younger animals. However, in vivo studies are useful to determine the pathogenic characteristics of TN296/07 and TN556/07 genotypes and evaluate the cross-protective level provided by the Mass H120 vaccine.

Moreover, when possible, it is important to evaluate periodically the cross-protective capabilities of vaccines versus recent field isolates. Outcomes of these studies will provide valuable information for better control of the disease using adequate preventive measures.

\section{Acknowledgments}

This work was fully supported by a grant from the Tunisian Ministry of Higher Education, Scientific Research and Technology.

\section{Disclosure}

The authors report no conflicts of interest in this work.

\section{References}

1. Cavanagh D. Coronaviruses in poultry and other birds. Avian Pathol. 2005;34:439-448.

2. Dolz R, Pujols J, Ordonez G, Porta R, et al. Antigenic and molecular characterization of isolates of the Italy 02 infectious bronchitis virus genotype. Avian Pathol. 2006;35:77-85.
3. Li H, Yang HC. Sequence analysis of nephropathogenic infectious bronchitis virus strains of the Massachusetts genotype in Beijing. Avian Pathol. 2001;30:535-541.

4. Moscoso H, Raybon EO, Thayer SG, et al. Molecular detection and serotyping of infectious bronchitis virus from FTA filter paper. Avian Dis. 2005;49:24-29.

5. Ladman BS, Loupos A B, Gelb Jr. Infectious bronchitis virus S1 gene sequence comparison is a better predictor of challenge of immunity in chickens than serotyping by virus neutralization. Avian Pathol. 2006;35:127-133.

6. Terregino C, Toffan A, Serena Beato M, et al. Pathogenicity of a QX strain of infectious bronchitis virus in specific pathogen free and commercial broiler chickens, and evaluation of protection induced by a vaccination programme based on the Ma5 and 4/91 serotypes. Avian Pathol. 2008;37:487-493.

7. Gelb J Jr, Weismann Y, Ladman BS, et al. S1 gene characteristics and efficacy of vaccination against bronchitis virus field isolates from the United States and Israel (1996 to 2000). Avian Pathol. 2005;34:194-203.

8. Wijimenga W. Survey of infectious bronchitis in Western Europe. Int Poultry Prod. 2009;17:23.

9. Smati R, Slim A, Guertin C, et al. Molecular characterization of three new avian infectious bronchitis virus (IBV) strains isolated in Quebec. Virus Genes. 2002;25:85-93.

10. Bourogâa H, Miled K, Gribaa L, et al. Characterization of new variants of avian infectious bronchitis virus in Tunisia. Avian Dis. 2009;53:426-433.

11. Bourogâa H, Miled K, Larbi I, et al. La bronchite infectieuse aviaire en Tunisie: séroprévalence, pathogénicité et étude de compatibilité vaccins-isolats. Arch Inst Pasteur Tunis. 2009;86:63-71.

12. Binns MM, Boursnell MEG, Cavanagh D, et al. Cloning and sequencing of the gene encoding the spike protein of the coronavirus IBV. J Gen Virol. 1985;66:719-726.

13. Falcone E, Amore E, Trani LDi, et al. Rapid diagnosis of infectious bronchitis virus by the polymerase chain reaction. J Virol Meth. 1997;64: 125-130.

14. Adzhar A, Shaw K, Britton P, Cavanagh D. Universal oligonucleotides for the detection of infectious bronchitis virus by the polymerase chain reaction. Avian Pathol. 1996;25:817-836.

15. Kingham BE, Keeler CL, Nix WA, et al. Identification of avian infectious bronchitis virus by direct automated cycle sequencing of the $\mathrm{S} 1$ gene. Avian Dis. 2000;44:325-335.

16. De Castro E, Sigrist CJA, Gattiker A, Bulliard V, et al. ScanProsite: detection of PROSITE signature matches and ProRule-associated functional and structural residues in proteins. Nucleic Acids Res. 2006;34:W362-W365.

17. Cavanagh D, Davis PJ, Cook JKA, et al. Location of the amino acid differences in the $\mathrm{S} 1$ spike glycoprotein subunit of closely related serotypes of infectious bronchitis virus. Avian Pathol. 1992;21: 33-34. 
18. Gelb Jr, Keeler CL, Nix WA, et al. Antigenic and S1 genomic characterization of the Delaware variant serotype of infectious bronchitis virus. Avian Dis. 1997;41:661-669.

19. Gelb Jr, Jackwood MW. Infectious bronchitis. In: Swayne DE, Glisson JR, Jackwood MW, editors. A Laboratory Manual for the Isolation and the Identification of Avian Pathogens. 4th ed. Kennett Square: American Association of Avian Pathologists; 1998:169-174.

20. Callison SA, Jackwood MW, Hilt DA. Molecular characterization of infectious bronchitis virus isolates foreign to the United States and comparison with United States isolates. Avian Dis. 2001;45: 492-499.

21. Kant A, Koch G, Van Roozelaar DJ, et al. Location of antigenic sites defined by neutralizing monoclonal antibodies on the $\mathrm{S} 1$ avian infectious bronchitis virus glycopolypeptide. J Gen Virol. 1992;73:591-596.

22. Cavanagh D, Ellis MM, Cook JKA. Relationship between variations in the S1 spike protein of infectious bronchitis virus and the extent of cross-protection. Avian Pathol. 1997;26:63-74.

23. Neil JD, Sosnovtsev S, Green KY. Recovery and altered neutralization specificities of chimeric viruses containing capsid protein domain exchanges from antigenically distinct strains of feline calicivirus. J Virol. 2000;74:1079-1084.
24. Lin KY, Wang HC, Wang CH. Protective effect of vaccination in chicks with local infectious bronchitis viruses against field virus challenge. $J$ Microbiol Immunol Infect. 2005;38:25-30.

25. Jackwood MW, Hilt DA, Williams SM, et al. Molecular and serologic characterization, pathogenicity, and protection studies with infectious bronchitis virus field isolates from California. Avian Dis. 2007;51: 527-533.

26. Cavanagh D, Mawditt K, Britton P, et al. Longitudinal studies of infectious bronchitis virus in broilers using genotype-specific quantitative PCRs. In: Heffels-Redmann U, Kaleta EF. Proceedings of the International Symposium on Infectious Bronchitis and Pneumovirus; June 24-27, 1996; Rauischhozhausen, Germany; 1998:215-219.

27. Abdel-Moneim AS, El-Kady M, Ladman BS, et al. S1 gene sequence analysis of a nephrophatogenic strain of avian infectious bronchitis virus in Egypt. Virol J. 2006;78:1-9.

28. Wang CH, Huang YC. Relationship between serotypes and genotypes based on the hypervariable region of the $\mathrm{S} 1$ gene of infectious bronchitis virus. Arch Virol. 2000;145:291-300.

29. Cavanagh D. Severe acute respiratory syndrome vaccine development: experiences of vaccination against avian infectious bronchitis coronavirus. Avian Pathol. 2003;32:567-582.

\section{Dovepress}

\section{Publish your work in this journal}

Veterinary Medicine: Research and Reports is an international, peer-reviewed, open access journal publishing original research, case reports, editorials, reviews and commentaries on all areas of veterinary medicine. The manuscript management system is completely online and includes a very quick and fair peer-review system.

Submit your manuscript here: http://www.dovepress.com/veterinary-medicine-research-and-reports-journal
Visit http://www.dovepress.com/testimonials.php to read real quotes from published authors. 